\title{
Is External Role of Public Managers and Organizational Internal Politics Able to Increase Sakai Ethnic Community Equity Satisfaction in the Tourism Sector?
}

\author{
${ }^{1 s t}$ Rizka Ratu Anastria ${ }^{1},{ }^{2 n d}$ Dasman Lanin ${ }^{2},{ }^{3 r d}$ Boni Saputra ${ }^{3}$ \\ \{ $\underline{\text { rizkaratuanastria@gmail.com }}{ }^{1}$, dasman@fis.unp.ac.id ${ }^{2}$, bonisaputra@ fis.unp.ac.id ${ }^{3}$ \} \\ Department of Magister Public Administration, Universitas Negeri Padang, Padang, Indonesia ${ }^{1}$ \\ Department of Public Administration, Universitas Negeri Padang, Padang, Indonesia ${ }^{2,3}$
}

\begin{abstract}
Public perception of the services provided by public organization will be assessed as good or not depending on whether the public service it receives matches or exceeds its expectations. This study aims to determine the role of the external public manager and internal politics of the organization in increasing the equity satisfaction of the Sakai ethnic community in the tourism sector. The method used in this study is a quantitative method with data collection methods through a questionnaire that is measured using a Likert scale and supported by documentation studies. The sampling technique used was purposive sampling. Respondents in this study were 230 Sakai ethnic communities in Bengkalis Regency. Data analysis was performed path analysis. The regression test results show thatthere is a significant influence between the external role of public managers and the internalpolitics of the organization on the equity satisfaction of the Sakai ethnic community in the tourism sector of the Bengkalis Regency.
\end{abstract}

Keywords: External Role, Internal Politics, Community Satisfaction, Tourism

\section{Introduction}

[1] Provides legal certainty for the implementation of public service activities in Indonesia. Article (1) Paragraph (1) explains that public service is an activity to fulfill service needs in accordance with statutory regulations for every citizen and resident for goods, services, and/or administrative services provided by public administrators. The government as a public organizer is responsible for providing quality services to the community in accordance with existing service standards. Service standards are benchmarks used as guidelines for service delivery and reference for assessing service quality as obligations and promises of administrators to the public in the framework of quality, fast, easy, affordable, and scalable. The quality of public services can be measured through the level of satisfaction of the service users. To create balanced satisfaction, internal (service provider), and external (community) customer satisfaction must also be balanced. 
Prior to 1975, studies on equity only focused on distributive justice, justice derived from the theory of equity "Equity Theory" [2] "fairness refers to how much people are aware of and compare themselves with other people's situations. People would attempt to maintain fairness by comparing the inputs (and outputs) that others bring to (and receive from) the same behavior. As long as the ratio between these inputs and output is equal, people may perceive the given situation to be fair. "Namely justice where if individuals provide a certain amount of input, the output received must be fair and proportional to the input that has been given. The idea suggests that a customer might expect to pay the same cost when obtaining the same benefits from the same transaction. If people notice that others get more benefits for their input, they will feel dissatisfied, and that can lead to feelings of unfairness [3]-[5]. Another discussion about perceived justice also accepts that perceived justice is often rooted in social comparative situations [6].

[7] have comprehensively carried out several reviews of the justice literature and classified it into three dimensions, namely, distributive justice, procedural, and interactional justice. Distributive equity is related to outcomes because the emphasis is on the distribution received, regardless of how it is determined [8]. [9] define the level of customer feelings of justice based on a comparison between benefits and costs. Distributive justice is felt by the customer when he feels that the value of equity, which is formed by comparing inputs and outputs during the exchange, is proportional to dozens of other reference points or references [10]. Procedural justice is defined as fairness to policies and processes that contribute to results [11]. The perceived fairness of the policies and procedures used by decision-makers in mediating disputes or negotiations [12], [13]. Interactional justice refers to the perceived fairness of an individual's treatment in accepting the decision-making process [12], [14].

Based on the results of research by [15], it can be seen that the influence of the role played by local governments on citizen satisfaction, the local government has made significant progress. As a result, increasing the role of managers will be able to increase citizen satisfaction in local government public services. According to Fred R. David, Realizing the organization's mission will be difficult if the organization does not interact with its external environment. Therefore, actions taken to determine and analyze the external environment are very important because external environmental conditions are beyond the control of the organization [16].

Indonesia is a country consisting of islands with diverse cultures, ethnicities, races, religions as well as characteristics and uniqueness of their respective regions. Based on the results of the 2010 BPS census, Indonesia has 1,340 ethnic groups in the country. The Javanese are the largest ethnic group in Indonesia, accounting for $41 \%$ of the total population. The division of ethnic groups in Indonesia at this time is not absolute and unclear, this is due to population displacement, cultural mixing, and mutual influence. [17] Each tribe generally has customary laws that regulate various aspects of life, ranging from aspects of social relations, beliefs, rituals of worship, myths.

This cultural diversity contributes to the public administration system in the context of local wisdom, so that from here it is formed a public administration that has its unique character. Public administration practices based on local wisdom have been going on for a long time in the days of kajan and the period before colonialism entered Indonesia and have been passed down from generation to generation and some still exist today. Local wisdom has recently become an aspect of conflict peace in public management. Ali Farazman's Sound Governance (strong government) really strengthens this local government. Public administration with the concept of public service management based on the values of our local wisdom deserves to be 
revived. Because local wisdom has recently become an aspect of conflict peace in public management.

Sakai ethnic group is one of the original ethnic groups in Riau Province, apart from theAkit Ethnic, the Talang Mamak Ethnic, and the Laut Ethnic. These ethnic groups are original ethnic communities in the interior of Riau belonging to the Veddoid race, with the characteristics of dark brown skin and curly, wavy hair. The height of the men is about $155 \mathrm{~cm}$ and the women $145 \mathrm{~cm}$. According to Moszkowski in [18] the Sakai people are Veddoid people mixed with Minangkabau people who migrated around the 14th century to the Riau area, precisely in Gasib, on the banks of the Gasib river upstream of the Rokan River. Gasib then became a kingdom, and then this kingdom was destroyed by the Aceh kingdom, and these people fled to the forests around the Gasib, Rokan, Mandau and tributary of Siak river. They are the ancestors of the Sakai people. Meanwhile, according to Boechari Hasan in [18] who obtained information about the origins of the Sakai people from Sakai's elders, the Sakai people came from Pagaruyung, Batusangkar, and from Mentawai.

Sakai ethnic population is spread from Riau to Jambi. However, most of them are found in Bengkalis Regency. The Ministry of Social Affairs noted that the number of Sakai people in Bengkalis was 4,995. The distribution of Sakai tribal settlements in Bathin Solapan District, Bengkalis Regency, namely in Kesumbo Ampai Village; Farmers Village (Belading hamlet + 112 families), and Bumbung Village (V Talang Jenang hamlet or Talang Nagoi village +60 families). The majority of Sakai people live in Kesumbo Ampai Village +173 families consisting of three hamlets, namely the Sebangar Asal hamlet; Patang Butam Hamlet; and the hamlet of Tanah Pujung. The majority of the Sakai tribe occupies the area of Sebanga Asal Hamlet where in this hamlet also stands the traditional house; surrounded by customary forest covering an area of $+260 \mathrm{Ha}$. [19]

Bengkalis is one of the regencies in Riau Province with an area of 7,793 km2 Geographical of Bengkalis Regency with a strategic position which is directly opposite to the Malacca Strait shipping and is in a growth triangle area, namely Indonesia - Malaysia - Singapore and Indonesia - Malaysia - Thailand [20] Bengkalis also has a natural charm and cultural diversity that can be used as a tourist attraction: 
Table 1. Tourism Objects of Bengkalis Regency

\begin{tabular}{|c|c|c|c|}
\hline No. & $\begin{array}{l}\text { Type of } \\
\text { Tourism } \\
\end{array}$ & Attraction Name & Location \\
\hline 1 & Natural & $\begin{array}{l}\text { (1) Giam Siak SK-BB Biosphere Reserve, (2) } \\
\text { Serai Lake, (3) Balai Raja Wildlife Forest, (4) } \\
\text { Tanjung Punak Mangrove Forest, (5) Sungai } \\
\text { Alam Mangrove Forest, (6) Sebauk, (7) } \\
\text { Tanjung Leban (8) Sukajadi }\end{array}$ & $\begin{array}{l}\text { (1) Siak Kecil, (2) Pinggir (3) } \\
\text { Pinggir, (4) North Rupat, (5) } \\
\text { Bengkalis, (6) Bengkalis } \\
\text { (7) Bandar Laksamana, (8) } \\
\text { Bukit Batu }\end{array}$ \\
\hline 2 & Artificial & $\begin{array}{l}\text { (1) Wisma Sri Mahkota Bengkalis, (2) } \\
\text { Andam Dewi Park, (3) Selatbaru Animal } \\
\text { Park, (4) Batu Ampar Park, (5) Duri Fishing } \\
\text { Park, (6) Elephant Training Center, (7) } \\
\text { Lelawangsa Golf Course }\end{array}$ & $\begin{array}{l}\text { (1) Bengkalis, (2) Bengkalis, } \\
\text { (3) Bantan, (4) Bengkalis, (5) } \\
\text { Mandau, (6) Duri, (7) } \\
\text { Bengkalis }\end{array}$ \\
\hline 3 & Nautical & $\begin{array}{l}\text { (1) Pesoma Beach, (2) Tanjung Lapin Beach } \\
\text { (3) Indah Selatbaru Beach, (4) Prapat } \\
\text { Tunggal Beach, (5) Ketapang Beach, (6) } \\
\text { Tenggayun Beach, (7) Aceh Beting Island, } \\
\text { (8) Bandar Sri Laksamana, (9) Cek Masayu } \\
\text { Fisherman Village, (10) Senekip Beach, (11) } \\
\text { Sesai Panjang Beach (11) Sekodi Beach, (12) } \\
\text { Sanloy Beach }\end{array}$ & $\begin{array}{l}\text { (1) Rupat Utara, (2) Rupat } \\
\text { Utara, (3) Bantan, (4) } \\
\text { Bengkalis, (5) Rupat, (6) Bukit } \\
\text { Batu, (7) Rupat Utara, (8) } \\
\text { Bengkalis, (9) Bengkalis, ( 10) } \\
\text { Pambang, (11) Simpang } \\
\text { Ayam, (12) Sekodi Bantan } \\
\text { Timur }\end{array}$ \\
\hline 4 & Culture & $\begin{array}{l}\text { (1) Rumah Datuk Laksamana Raja Dilaut, (2) } \\
\text { Dutch Heritage Prison, (3) Titi Akar Temple } \\
\text { (5) Hok Ahn Kiong Temple (6) Zapin } \\
\text { Village, (7) Sultan Syarif Qasim Museum (8) } \\
\text { House of the Long Forest Akit Tribe (9) } \\
\text { Traditional House of Sakai Kesumbo Ampai } \\
\text { Tribe, 10) LAM Building }\end{array}$ & $\begin{array}{l}\text { (1) Bukit Batu, (2) Bengkalis, } \\
\text { (3) Rupat, (4) Bengkalis, (5) } \\
\text { Bengkalis, (6) Bengkalis, (7) } \\
\text { Rupat, (8) Duri (9) Bengkalis }\end{array}$ \\
\hline 5 & History & $\begin{array}{l}\text { (1) Tomb of Panglima Minal, (2) Tomb of the } \\
\text { Nawaluh Damanik, (3) Tomb of Datuk } \\
\text { Admiral the King of the Sea, (4) Tomb of } \\
\text { Tengku Baus Said Toha, (5) Tomb of } \\
\text { Commander Kenaik, (6) Tomb of Dara } \\
\text { Sembilan, (7) ) Tomb of Princess Nine }\end{array}$ & $\begin{array}{l}\text { (1) Bengkalis, (2) Bengkalis, } \\
\text { (3) Bukit Batu, (4) Bengkalis, } \\
\text { (5) Bengkalis, (6) Bengkalis, } \\
\text { (7) North Rupat }\end{array}$ \\
\hline 6 & Agriculture & Mentayan Tourism Village & Bantan \\
\hline 7 & Culinary & $\begin{array}{l}\text { (1) Taman Che 'Mehaten, (2) Pujasera } \\
\text { Ahmad Yani, (3) Pujasera Sudirman }\end{array}$ & $\begin{array}{l}\text { (1) Bengkalis (2) Bengkalis (3) } \\
\text { Duri }\end{array}$ \\
\hline 8 & Shopping & $\begin{array}{l}\text { (1) Sukaramai Market, (2) Mandau City, (3) } \\
\text { Plaza Laksamana }\end{array}$ & $\begin{array}{l}\text { (1) Bengkalis, (2) Duri (3) } \\
\text { Bengkalis }\end{array}$ \\
\hline 9 & Religious & $\begin{array}{l}\text { (1) Jami 'Kelapa Pati Laut Mosque, (2) } \\
\text { Istiqomah Mosque, (3) Yellow Mosque }\end{array}$ & $\begin{array}{l}\text { (1) Bengkalis (2) Bengkalis (3) } \\
\text { Bengkalis }\end{array}$ \\
\hline
\end{tabular}

Source: Department of Tourism, Culture, Youth and Sports of Bengkalis Regency (2020) 
From the table above we can see the various types of tourism found in the Bengkalis Regency so that the Bengkalis Regency has great potential for tourism development. The natural potential of Bengkalis Regency which is still quite good, peat swamp forests, beaches, and small islands as well as the potential of indigenous tribes are the main attractions for visitors. Local government as a public manager must be able to explore and develop the tourism potentials in Bengkalis Regency. Bengkalis Regency Government itself plans to develop a tourist attraction to become a prospective commodity if it is supported by the provision of tourist facilities. In its development, it is an opportunity for tourism development, but as a whole, it has not been managed optimally. This can be seen from the availability of tourist facilities, namely transportation routes that still need improvement, both land and sea transportation, the lack of clean water availability, and the lack of accommodation such as the availability of lodging and rides that can attract tourists. Some tourist objects are also not well managed, so they are just neglected.

The development of this tourist attraction requires management and implementation that involves all levels, not only involving the role of the government but also the role of the community and stakeholders who will later become part of the manager or implementer of the development of tourist objects in Bengkalis Regency. Therefore, this is one of the external roles of public managers or the government in synergizing this layer. Theoretically, the role of managers can be grouped into two groups, namely internal roles, and external roles. The internal role is related to the manager's relationship with employees, which creates job satisfaction in their work, and the external role is related to the manager's relationship with citizens that can generate citizen satisfaction. [15]

Miles in [21] defines organizational politics as a process in which actors or organizational groups build "power" to influence the setting of objectives, criteria, or operational decisionmaking processes to fulfill their interests. Nelson \& Quick in [22] defines organizational politics as the use of power and influence in the organization. Organizational politics in this case refers to the need to power and influence someone. Therefore, organizations should use organizational politics in managing and increasing the work productivity of their employees. According to Thompson \& Ingraham [23]

Subarsono states that the old habit of siding with cronies and certain political groups is still prevalent in public services in Indonesia. Civil servants as the political vehicle for the Golkar Party during the New Order era still influenced the quality of public services in Indonesia. [23] in his study included conditions as an organizational internal political variable: favoritism by insiders when providing services, services that were influenced by political pressure from powerful officials, and services provided to certain individuals only. Game-based services in the government bureaucracy are easily visible in district and city governments, for example, the provision of various government assistance, such as Small Business Credit and the administration of Identity Cards [24]. This kind of game, [23] conducted a study on citizens' perceptions of politics and ethics in public administration. The results show a meaningful direct and indirect relationship between organizational politics and ethics in the public sector, satisfaction, trust, and voice orientation. [23] Found that two factors that drive citizen satisfaction in public services are internal organizational politics and ethics. 
Research by [25] has found a Local Government Service Model for Customer Satisfaction based on TQM in a hospital. Then [25] 2 have tested this model in three public sectors, namely the Immigration sector, the Industry and Labor sector, and the Population and Civil Registry sector, the results show that this model is consistent and shows a significant influence between internal customer satisfaction ( employees) with 6 intermediate variables or service transactions (delivery, timeliness, professionalism, information, staff attitude, organizational internal politics) and vice versa also seen significant service transactions with external customer satisfaction.

Departing from the phenomenas and theories above, the researcher want to know about the correlations between external manager role, organizational internal politics on community satisfaction. The researcher feels the need to conduct a research on the tourism sector with the object of research on the Sakai ethnic group in Bengkalis Regency, which will explore and reveal: whether the external role of public managers affects the increase in equity satisfaction of the Sakai ethnic community through internal organizational politics directly and also indirectly or through intermediary variables, either partially nor simultaneously.

\section{Methodology}

Based on the background of the problem and problem formulation described in the previous chapter, the research method used is quantitative research with surveys method. The research subjects was Sakai ethnic community in Bengkalis Regency with a sample of 230 respondents. Sampling was done using simple random sampling technique. The data used in this study are primary data and secondary data. Data collection was carried out using a research instrument in the form of a questionnaire or questionnaire, which was carried out by distributing a list of written statements and questions to respondents to obtain answers to the questions posed and then measured using a Likert scale. The validity and reliability of the questionnaires that were distributed previously had been tested. Validity testing is carried out using the Pearson Product Moment correlation with a correlation coefficient $\geq 0.3$, so the instrument items are declared valid. A reliability test is also carried out to determine the consistency of measuring instruments used so that if the measuring instrument is used again to examine the same object with the same technique even though the time is different, the results obtained will be the same. An instrument is said to be reliable if it has a Cronbach Alpha value $\geq 0.60$ (Hair et al., 2010). then the results obtained will be the same. An instrument is said to be reliable if it has a Cronbach Alpha value $\geq 0.60$ (Hair et al., 2010). then the results obtained will be the same. An instrument is said to be reliable if it has a Cronbach Alpha value $\geq 0.60$ (Hair et al., 2010).

In this study, the authors wanted to know the causal relationship of the influence between variables, namely variables X1 (external manager role), X2 (organizational internal politic) on variable Y (community satisfaction) Sakai ethnicity in Bengkalis.Before being analyzed by using path analysis, a classic assumption test was carried out which consisted of a normality test, linearity test, multicollinearity test, and heteroscedasticity test, after which the hypothesis test was carried out using multiple regression analysis. The purpose of using regression analysis is to estimate the mean and value of independent variables based on the value of dependent variables, to test the dependent characteristics hypothesis, to predict the mean value of independent variables based on the value of dependent variables outside the sample range. In 
this study, the concepts of variables studied were three variables: external role of public manager, organizational internal politic, and public satisfaction.

\section{Finding and Discussion \\ Research Demographic Characteristics}

The characteristics of respondents in this study can be described as a whole and generally in this following table:

Table 2. Characteristics of Respondents

\begin{tabular}{|c|c|c|}
\hline Respondent Characteristics & Amount & Percentage \\
\hline \multicolumn{3}{|l|}{ Gender } \\
\hline Male & 100 & $43 \%$ \\
\hline Women & 130 & $57 \%$ \\
\hline Amount & 230 & $100 \%$ \\
\hline \multicolumn{3}{|l|}{ Age } \\
\hline Under 20 years & 8 & $3 \%$ \\
\hline $21-30$ years & 84 & $37 \%$ \\
\hline $31-40$ years & 52 & $23 \%$ \\
\hline $41-50$ years & 51 & $22 \%$ \\
\hline Over 50 years & 35 & $15 \%$ \\
\hline Amount & 230 & $100 \%$ \\
\hline \multicolumn{3}{|l|}{ Level of education } \\
\hline Elementary School & 47 & $20 \%$ \\
\hline Junior High School & 43 & $19 \%$ \\
\hline High school & 87 & $38 \%$ \\
\hline DI / DII / DII & 10 & $4 \%$ \\
\hline S1 & 43 & $19 \%$ \\
\hline Amount & 230 & $100 \%$ \\
\hline
\end{tabular}

Source: Research Results 2020 (data processed)

From table 2 above, it can be seen that the demographic characteristics of this study can be grouped based on three types of groups, namely gender, age, and education level. For the gender group, respondents were predominantly female, namely 57\%, the age group was 21-30 years old and the highest level of education was at the senior high school level, namely $38 \%$.

\section{Hypothesis Test Results}

The Statistical data in this study processing using multiple linear regression analysis. Previously, the data had been tested for the prerequisites of classical assumptions. The classical assumption test includes 1) normality test; 2) linearity test; 3) heteroscedasticity test; and 4) multicollinearity test. The classical assumption test analysis is proven to meet the requirements and has passed the prerequisite test so that the data is declared worthy of analysis at the next stage, namely the regression test. The results of the regression test can be seen in the table below: 
Table 3. Regression Test Results

\begin{tabular}{llllll}
\hline \multicolumn{1}{c}{ Model } & R & R Square & $\begin{array}{c}\text { Adjusted } \\
\text { R Square }\end{array}$ & Sig. \\
\hline $\begin{array}{l}\text { The influence of the external role of public managers } \\
\text { on the equity satisfaction of the Sakai ethnic } \\
\text { community in the tourism sector }\end{array}$ & $.451 \mathrm{a}$ & .168 & .168 & .000 \\
\hline $\begin{array}{l}\text { The influence of the organization's internal politics } \\
\text { on the equity membership of the Sakai ethnic } \\
\text { community in the tourism sector }\end{array}$ & $.286 \mathrm{a}$ & .082 & .078 & .000 \\
\hline 3. & & & .069 & .065 & .000 \\
& The influence of the external role of public managers \\
on the internal politics of the organization & .262 & & & \\
\hline
\end{tabular}

From the table above, it can be seen that the influence and contribution of each independent variable on dependent variables can be seen. The results of the statistical data analysis prove that each independent variable is proven to have a significant effect on the Sakai ethnic equity satisfaction in the tourism sector. This is evidenced by the acquisition of a significant value which is below $<0.05$. The significance here also means that the effect of each independent variable on the dependent variable has a real and significant effect. The contribution of influence given is of course different in each variable, but it can be concluded that the greatest contribution occurs in the external role variable of public managers, namely with a contribution of influence of $16.8 \%$.

a. The Influence of External Roles of Public Managers on Community Equity Satisfaction

Based on the results of statistical testing it prove that the research hypothesis has shown significant results with the effect value of $16.8 \%$ given by the external role of public managers on the equity satisfaction of the Sakai ethnic community, this is evidenced by the value of the regression analysis with a significance value of 0.000 . These results reflect that empirically the external role variable of public managers has had a significant positive effect on the equity satisfaction of the Sakai ethnic community in the tourism sector.

\section{b. The Influence of Organizational Internal Politics on Community Equity Satisfaction}

Based on the results of statistical testing it prove that the research hypothesis has shown significant results with an effect value of $7.8 \%$ given by internal organizational politics on equity satisfaction of the Sakai ethnic community, this is evidenced by the value of the regression analysis results with a significance value of 0.000 . These results reflect that empirically the internal political variables of the organization have had a significant positive effect on the equity satisfaction of the Sakai ethnic community in the tourism sector. This is consistent with the results [15]

\section{c. The Influence of the External Role of Public Managers on the Internal Politics of the Organization}

Based on the results of statistical testing it prove research hypothesis has shown significant results with an effect value of $6.5 \%$ given the external role of public managers on the internal politics of the organization, this is evidenced by the value of the results of regression analysis with a significance value of 0.000 . These results reflect that empirically the external role 
variable of public managers has a significant positive influence on the internal politics of the organization.

\section{d. Summary of Model Analysis and Testing}

The model conceptualized in this study is to explain and determine the influence of the external role of public managers on the satisfaction of public equity satisfaction either directly or indirectly or through the organization's internal political intermediary variables. The conception of research is to prove whether or not the causal (independent) variable influences the consequent (dependent) variable. The data were analyzed using path analysis, which previously carried out the classical assumption test and regression test. The summary results of the model are as shown in the figure and table below:

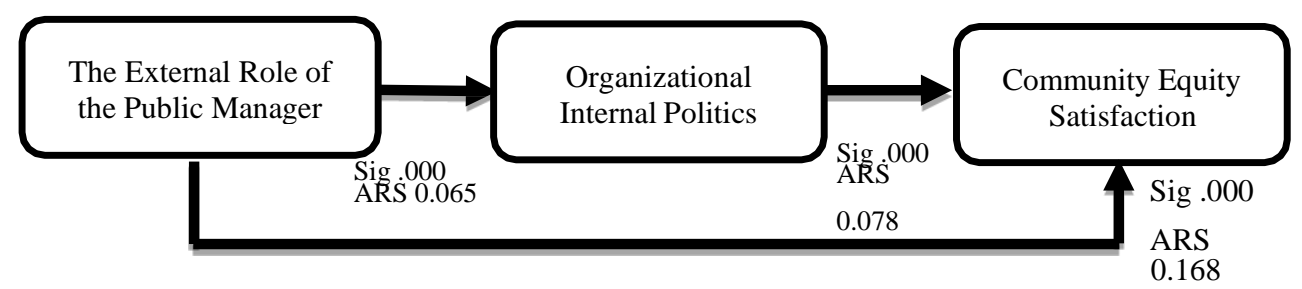

Figure 1. Summary of Regression Test Results (Source: Results of Research Data Processing, 2020)

Based on the picture above, it can be describe that the shape of the relationship and the magnitude of the contribution of the influence of each independent variable to the dependent variable. In this study, it can be seen that all independent variables have a significant effect on the dependent variables, and the amount of contribution made varies and varies in each of the variables. The picture above also shows the direction of the arrow which implies a relationship of influence either directly or indirectly. To see how much the contribution of the indirect effect (through intermediate variables) can be seen in the table below

Table 3. Summary of Model Parameter Estimation Results

Variable Direct Influence Indirect Influence

The influence of the external role of public managers on public equity satisfaction through organizational $16.8 \%$ $0.52 \%$ internal political variables

Source: Research Results 2020 (data processed)

The table above describes the results of the path analysis of the direct effect and the indirect effect that occurs or is caused by each independent variable on the dependent variable. The contribution of influence that occurs through organizational politics is $0.52 \%$. 


\section{Conclusion}

This study aims to determine the influence of the external role of public managers on the equity satisfaction of the Sakai people through the internal politics of the organization, either directly or indirectly, in the tourism sector. After conducting the research, data processing, and discussion, in this study, it can be concluded that:

1) There is a direct effect of the external role of public managers on the satisfaction of public equity by $16.8 \%$ with a significance value of 0.000 and the effect is positive;

2) There is an influence of internal organizational politics on community satisfaction by $7.8 \%$ with a significance value of 0.000 and the effect is positive;

3) There is a direct influence of the external role of public managers on the internal politics of the organization by $6.5 \%$ with a significance value of 0.000 and the influence is positive;

4) There is an indirect effect of the variable external role of public manager on public equity satisfaction of $0.52 \%$ with a significance value of 0.000 and the effect is positive;

Based on the result above it can be conclude that external role of public managers and organizational internal politics able to increase sakai ethnic community satisfaction in the tourism sector. Through this research, it can also be suggested to Department of Tourism, Culture, Youth and Sports of Bengkalis Regency that in increasing public equity satisfaction,it should still pay attention to the factors of the external role of public managers and internal politics of the organization; Given that the external role variable of public managers is the variable that most influences the satisfaction of public equity and is the variable that has the most dominant/large contribution to the influence, it is advisable to the Department of Tourism, Culture, Youth and Sports of Bengkalis Regency, to keep paying attention and prioritizing the role. external public manager in tourism. Due to the writer's limited resources in researching,

\section{Acknowledgments}

The author congratulates the Institute for Research and Community Service (LP2M) Padang State University for the assistance of PNBP research funds for the 2020 fiscal year. The author also thanks to the Bengkalis Regency government in this case the District Tourism, Culture, Youth and Sports Office Bengkalis, and the Sakai ethnic community where this research was conducted and thanks to the research team, so that this research can be completed on time.

\section{References:}

[1] Undang-Undang Nomor 29 Tahun 2012 tentang Public Service. 2012.

[2] L. Tseng en C. Kuo, "Customers 'Attitudes Toward Insurance Frauds: An Application of Adams’ equity Theory”, Int. J. Soc. Econ., 2014.

[3] J. Brockner, J. Greenberg, A. Brockner, J. Bortz, J. Davy, en C. Carter, "Layoffs, equity theory, and work performance: further evidence of the impact of survivor guilt", Acad. Manag. J., vol 29, no 2, bll 373-384, 1986.

[4] I. Ajzen, L. H. Rosenthal, en T. C. Brown, "Effects of perceived fairness on willingness topay"”, J. Appl. Soc. Psychol., vol 30, no 12, bll 2439-2450, 2000. 
[5] J. Lopes en C. Fletcher, "Fairness of impression management in employment interviews:a cross-country study of the role of equity and Machiavellianism", Soc. Behav. Pers., vol 32, no 8, bll 747-768, 2004.

[6] T. W. Taris, R. Kalimo, en W. . Schaufeli, "Inequity at work: its measurement and association with worker health", Work Stress, vol 16, no 4, bll 287-301, 2002.

[7] J. A. Colquitt, "On the dimensionality of organizational justice: a construct validation of a measure”, Organ. justice a Constr. Valid. a Meas. J., vol 86, no 3, bl 386, 2001.

[8] N. Magner en G. G. Johnson, "Municipal Officials'reactions To Justice In Budgetary Resource Allocation", Public Adm. Q., bll 439-456, 1995.

[9] M. Olsen en D. Johnson, "Service Equity, Satisfaction, and Loyalty: From TransactionSpecific to Cumulative Evaluations", J. Serv. Res., vol 5, no 3, bll 186-195, 2003.

[10] J. A. Sindhav, P. T. R. Holland, P. T. Rodie, en L. G. P. Adidam, "The Impact of Perceived Fairness on Satisfaction: are Airport Security Measures Fair? Does it Matter", J. Mark. Theory Pract., vol 14, no 4, bll 323-335, 2006.

[11] E. A. Lind en T. R. Tyler, The Social Psychology of Procedural Justice. Springer Science \& Business Media, 1988.

[12] V. Martinez-Tur, J. M. Peiro, J. Ramos, en C. Moliner, "Justice Perceptions as Predictors of Customer Satisfaction: The Impact of Distributive, Procedural, and Interactional Justice", J. Appl. Soc. Psychol., vol 36, no 1, bll 100-119, 2006.

[13] C. M. Voorhees en M. K. Brady, "A service perspective on the drivers of complaint intentions", J. Serv. Res., vol 8, no 2, bll 192-204, 2005.

[14] J. Y. Son en S. S. Kim, "Internet Users' Information Privacy-Protective Responses: A Taxonomy And A Nomological Model”, MIS Q., bll 503-529, 2008.

[15] D. Lanin, "Citizen Satisfaction with Local Government Service: The Influence of Manager Role on Public Service Improvement in Local Government", J. Tingkap, vol 10, no 2, 2014, [Online]. Available at: http://ejournal.unp.ac.id/index.php/tingkap/issue/view/522.

[16] U. Husein, Marketing Research And Consumer Behavior. Jakarta: PT Gramedia Pustaka Utama, 2005.

[17] "No Title". https://indonesia.go.id/profil/suku-bangsa.

[18] Isdarwanto, Totok, and Zulfa Zulfa. "Suku Sakai dalam Tiga Kekuasaan di Riau." Jurnal Ilmu Budaya 7.1 (2010): 1-11.

[19] Bakar, Abu, and Abd Ghofur. "Problematika Pemberdayaan Komunitas Adat Terpencil (KAT) Suku Sakai di Kecamatan Bathin Solapan Kabupaten Bengkalis." TOLERANSI: Media Ilmiah Komunikasi Umat Beragama 9.1 (2017): 91-113.

[20] "Indonesia Ecoturism Network", 2002. .

[21] Siswanto, "Politik Dalam Organisasi: Suatu Tinjauan Menuju Etika Berpolitik", J. Manaj., vol 10, no 4, bll 159-165, 2007.

[22] F. Wulani, "Analisis Hubungan Politik dan Dukungan Organisasional Dengan Sikap Kerja, Kinerja, dan Perilaku Citizenship Organisasional”, Univ. Widya Mandala Surabaya, vol 8, no 2, bll 111-132, 2004.

[23] E. Vigado-Gadot, "Citizen's Perceptions of Politics and Ethics in Public Administration: A Five-Year National Study of Their Relationship to Satisfaction with Services, Trustin Governance, and Voice Orientations", in JPART, vol 17, Oxford, 2008.

[24] A. G. Subarsono, Analisis Kebijakan Publik: Konsep Teori dan Aplikasi. Yogyakarta: Pustaka Pelajar, 2006.

[25] D. Lanin en Syamsir, "Model Pelayanan Pemerrintah Daerah yang Memuaskan Pelanggan Internal dan Eksternal Berbasis Total Quality Management; di RSUD Padang Panjang", Padang, 2017. 